\title{
Pengembangan Bahan Ajar Matematika Bernuansa Islam Dilengkapi Rumus Cepat Materi Aritmatika Sosial
}

\author{
Umi Afifah ${ }^{1 *}$, Ruhban Masykur ${ }^{2}$, Rizki Wahyu Yunian Putra ${ }^{3}$, \& Riyama Ambarwati ${ }^{4}$ \\ 1,2,3,4 Universitas Islam Negeri Raden Intan Lampung, Bandar Lampung, Indonesia
}

\section{INFO ARTICLES}

Article History:

Received: 09-11-2021

Revised: 06-12-2021

Approved: 18-12-2021

Publish Online: 31-12-2021

\section{Key Words:}

Mathematics Teaching Materials; Social Arithmetic; Islamic Nuances; Mathmagic;

\begin{abstract}
Development research was carried out by researchers as an innovation in teaching materials for social arithmetic with Islamic nuances equipped with mathmagic that was valid, attractive and effective to support the learning process. The type of research used is development research using the ADDIE model. The data analysis technique used is validation analysis of material and media experts and religious experts, student response analysis, and effect size test. The sampling technique used is cluster random sampling. The results of the feasibility test of the material and media validator and religious experts with valid criteria. The attractiveness test on the small-scale test with very interesting criteria and on the large-scale test with very interesting criteria. The Assessment of the effectiveness test got an effect size test score of 0.43 with a medium category which means it has an influence in improving student learning outcomes and is effective for use during learning.
\end{abstract}

Abstrak: Penelitian pengembangan dilakukan sebagai inovasi bahan ajar materi aritmatika sosial bernuansa Islam dilengkapi rumus cepat yang valid, menarik, dan efektif untuk mendukung proses pembelajaran. Jenis penelitian yang digunakan adalah penelitian pengembangan menggunakan model ADDIE. Teknik analisis data yang digunakan adalah analisis validasi ahli materi dan media serta ahli agama, analisis respon peserta didik, dan uji effect size. Teknik sampling yang digunakan adalah cluster random sampling. Hasil uji kelayakan dari validator materi dan media serta ahli agama dengan kriteria valid. Uji kemenarikan pada uji skala kecil dengan kriteria sangat menarik dan pada uji skala besar dengan kriteria sangat menarik. Penilaian uji efektivitas mendapatkan skor uji effect size sebesar 0,43 dengan kategori sedang yang artinya memiliki pengaruh dalam meningkatkan hasil belajar peserta didik dan efektif untuk digunakan saat pembelajaran.

Correspondence Address: Jln. Raya Lintas Pantai Timur Sumatera, Way Jepara, Lampung Timur, Lampung, Indonesia, Kode Pos 34396; e-mail: umiafifah1115@gmail.com

How to Cite (APA 6 ${ }^{\text {th }}$ Style): Afifah, U., dkk. (2021). Pengembangan Bahan Ajar Matematika Bernuansa Islam Dilengkapi Rumus Cepat Materi Aritmatika Sosial. JKPM (Jurnal Kajian Pendidikan Matematika), 7(1): 59-70. http://dx.doi.org/10.30998/jkpm.v7i1.11330

Copyright: 2021 Umi Afifah, Ruhban Masykur, Rizki Wahyu Yunian Putra, Riyama Ambarwati

Competing Interests Disclosures: The authors declare that they have no significant competing financial, professional or personal interests that might have influenced the performance or presentation of the work described in this manuscript. 


\section{PENDAHULUAN}

Matematika merupakan cabang ilmu pendidikan yang berperan penting dalam perkembangan ilmu pengetahuan dan teknologi, baik sebagai alat bantu dalam implementasi bidang ilmu lain ataupun dalam pengembangan ilmu matematika itu sendiri. Era persaingan yang semakin kompetitif pada saat ini, peserta didik diharuskan menguasai materi matematika dalam penataan nalar serta pemecahan masalah. Matematika merupakan ilmu yang bermanfaat untuk sebagian besar untuk ilmuilmu lain, karena bukanlah ilmu yang hanya untuk keperluan dirinya sendiri, maka makna lain matematika adalah ilmu yang memiliki peran yang sangat esensial bagi ilmu lain, terutama bidang sains dan teknologi (Siagian, 2016). Pembelajaran matematika dilaksanakan di semua jenjang pendidikan dalam rangka membentuk cara berpikir peserta didik dalam pemecahan masalah dengan berpikir kritis, sistematis serta logis. Matematika sangat berpengaruh bagi bidang ilmu pendidikan lainnya karena dapat menumbuhkan cara berpikir peserta didik.

Pembelajaran matematika bagi peserta didik merupakan pembentukan pola pikir dalam pemahaman suatu pengertian maupun dalam penalaran suatu hubungan diantara pengertianpengertian itu (Arifah \& Saefudin, 2017). Matematika merupakan tahapan guna menghasilkan jawaban untuk suatu masalah yang dihadapi. Tahapan menggunakan informasi menggunakan pengetahuan mengenai menghitung serta yang terpenting adalah pemikiran dalam diri manusia untuk melihat dan menggunakan hubungan-hubungan, sehingga bisa diartikan bahwa belajar matematika dapat membuat kita menemukan jawaban atas suatu masalah yang dihadapi yang berhubungan dengan matematika (Fitriyana, et. al., 2021). Pada setiap individu memiliki kemampuan untuk memproses informasi pada otaknya dan cara setiap manusia satu dengan manusia yang lainnya tidak sama. Matematika tentunya tidak jarang dianggap ilmu jadi atau produk yang harus ditransfer ke dalam pikiran peserta didik, tanpa mementingkan proses. Oleh karena itu jika matematika diasumsikan berupa produk, pendidik tentunya lebih condong mentransfer pengetahuan tentang materi matematika yang dikuasai kepada peserta didik. Berbeda jika pendidik beranggapan matematika merupakan suatu proses, maka dalam belajar mengajar matematika adalah suatu usaha guna membimbing dan mendukung peserta didik untuk memecahkan suatu masalah melalui proses. Pada pelaksanaan pembelajaran di sekolah saat ini nyatanya tidak sedikit yang masih beranggapan bahwa matematika sebagai produk. Oleh karena itu pendidik berusaha mentransfer pengetahuan yang dimiliki kedalam pikiran peserta didik.

Hasil belajar peserta didik yang rendah diakibatkan karena peserta didik memiliki pemahaman konsep yang cukup rendah pada materi yang disampaikan, utamanya dalam menyusun model matematika (Situorang, 2017; Rachmawaty, 2020). Wawancara yang dilakukan pada pra-penelitian menghasilkan kesimpulan dari pendidik bahwa perlu adanya peningkatan sikap spiritual peserta didik. Penanaman nilai-nilai agama dalam kehidupan sehari-hari peserta didik dapat dilakukan guna meningkatkan sikap spiritual yang diharapkan dengan adanya suatu bahan ajar yang memuat nuansa Islam. Pokok materi yang terdapat pada buku belum dapat tersampaikan secara baik kepada peserta didik dikarenakan skurangnya ilustrasi yang komunikatif dan interaktif dalam buku matematika serta bahasa yang digunakan kurang efektif. Modul dapat digunakan dalam pembelajaran guna membantu dan menjadi salah satu solusi dari permasalahan di atas. Perlunya pengembangan pembelajaran dimana peserta didik leluasa untuk mengengembangkan pola pikirnya dengan aktif serta kreatif guna pemecahan masalah yang ditemui.

Cabang ilmu matematika memiliki banyak sub yang diantaranya terdapat materi aritmatika sosial, di dalamnya memuat perhitungan untung, rugi, bruto, tara, neto, bunga tabungan, pajak, dan lain-lain. Rumus yang banyak harus diingat dan dipahami oleh peserta didik, membuat teori pada materi aritmatika sosial dianggapan sebagai meteri yang tidak mudah dan peserta didik dituntut mampu mengaabstraksikan/memgambarkan sebuah teori kedalam kehidupan sehari-hari (Sina, 2011; Mulyatna, et. al., 2021). Pada hal ini tentunya peserta didik sering mengalami masalah untuk menggambarkan dalam pikiran suatu teori yang diimplementasikan ke kehidupan sehari-hari. 
Pemahaman konsep adalah bagian penting dalam proses pembelajaran matematika, sedangkan pada pembelajaran matematika peserta didik masih mengalami banyak kesulitan, utamanya yang berhubungan dengan konsep, teorema, definisi, dan pembuktian. Kesulitan yang ditemui mengakibatkan peserta didik merasa jenuh dan bosan pada proses pembelajaran (Putra \& Anggraini, 2016). Pengembangan bahan ajar merupakan salah satu cara yang dapat dilakukan pendidik guna mengurangi kesulitan belajar. Susun susunan sistematis dari sekumpulan materibagi peserta didik untuk kegiatan pembelajaran adalah makna bahan ajar (Hamdani, 2011). Penelitian memiliki tujuan mengembangkan bahan ajar guna membantu peserta didik memahami materi dan belajar secara mandiri.

Rumus cepat biasa dikenal dengan mathmagic. Metode ini diaplikasikan bagi peserta didik yang telah mengetahui dan mengerti konsep dasar matematika. Adanya metode ini memungkinkan peserta didik mampu menyelesaikan ujian dalam keterbatasan waktu yang sudah diberikan (Herdianto, et. al., 2018). Rumus cepat diterapkan sebagai alat pembanding hasil pembelajaran dalam menyelesaikan soal menggunakan rumus baku dibandingkan penyelesaian menggunakan rumus cepat. Peserta didik dapat menggunakan rumus cepat supaya waktu yang dikeluarkan lebih singkat, memudahkan peserta didik dalam memahami materi. Guna menumbuhkan rasa percaya diri dan minat belajar peserta didik penggunaan rumus cepat dapat dilakukan dalam menyelesaikan soal-soal matematika.

Seperti yang diketahui pada saat ini moral anak bangsa sudah menurun. Sikap spiritual yang menurun dan adanya kesulitan-kesulitan yang dihadapi peserta didik dalam pembelajaran membuat peneliti menyimpulkan bahwa perlu adanya suatu bahan ajar yang dapat meningkatkan minat belajar, efektif, dan dapat membantu mengembangkan sikap spiritual peserta didik.

\section{METODE}

Pada pengembangan bahan ajar berupa modul yang dilakukan, peneliti menggunakan metode pengembangan Research and Development (R\&D). Metode ini dapat diaplikasikan guna menguji keefektifan produk yang dihasilkan serta menghasilkan suatu produk yang baru (Sugiyono, 2017). Peneliti melakukan penelitian serta pengembangan dengan tujuan menghasilkan bahan ajar berupa modul dengan pokok materi aritmatika sosial bernuansa Islam dilengkapi rumus cepat. Penelitian ini dilaksanakan di salah satu MTs Swasta di Sukarame, Bandar Lampung. Pengembangan yang dilakukan berupa bahan ajar matematika kelas VII SMP/MTs bernuansa Islam pada materi aritmatika sosial dilengkapi rumus cepat. Perancangan penelitian ini dilakukan dengan metode Research and Development (R\&D) menggunakan model ADDIE. Guna terciptanya bahan ajar yang menarik, efektif dan efisien model ADDIE ini memuat proses sistematis yang dapat membantu, serta dapat menciptakan lingkungan belajar yang mendukung dengan adanya perpaduan antara seni, teori, ilmu pengetahuan, dan proses belajar mengajar (Aldoobie, 2015). Analysis (analisis), design (desain), development (pengembangan), implementation (implementasi), dan evaluation (evaluasi) merupakan tahapan yang ada pada model pengembangan ADDIE (Mardati, 2017).

Teknik dalam pengambilan sampel adalah teknik cluster random sampling. Penelitian dilakukan dengan pengambilan tiga kelas sebagai sampel. Subjek dari penelitian ini adalah peserta didik kelas VIII. Populasi dalam penelitian ini adalah peserta didik kelas VIII di salah satu MTs Swasta di Sukarame, Bandar Lampung, dimana terdapat lima kelas.

Teknik pengumpulan data dilakukan dengan adanya instrumen, yaitu pedoman wawancara yang berisi kumpulan pertanyaan yang akan disampaikan pada kegiatan wawancara pada fase analisis kebutuhan. Wawancara dilakukan dengan guru, lalu peneliti menganalisis hasil tes ujian harian peserta didik pada materi aritmatika sosial. Setelah tahap pengembangan produk, dilakukan validasi oleh ahli materi dan media serta ahli agama dengan diberikan angket validasi produk yang dikembangkan. Lembar angket penilaian para ahli berguna untuk mengukur kelayakan dari produk yang dikembangkan sebelum diimplementasikan dalam proses pembelajaran. Lembar angket respon 
peserta didik untuk mengetahui kemenarikan dari produk yang dikembangkan. Kemudian lembar pretest dan postest guna mengukur Efektivitas dari produk yang telah dikembangkan.

Teknik analisis data yang dilakukan menggunakan teknik analisis deskriptif kuantitatif, selanjutnya data yang semula berupa skor diubah menjadi data kualitatif dengan skala empat. Teknik analisis data kelayakan menggunakan skor rata-rata akhir penilaian oleh validator yang diperoleh dari Skala Likert. Adapun 4 acuan kriteria, guna mengetahui tingkat kevalidan pada angket validasi ahli terhadap bahan ajar yang dikembangkan mengacu pada Tabel 1 ..

Tabel 1. Kriteria Validasi (Dimodifikasi)

\begin{tabular}{ccc}
\hline Skor Kualitas & Kriteria & Keterangan \\
\hline $3,26<\bar{x} \leq 4,00$ & Valid/sangat layak digunakan & Tidak Revisi \\
$2,51<\bar{x} \leq 3,26$ & Cukup Valid/layak digunakan & Revisi Sebagian \\
$1,76<\bar{x} \leq 2,51$ & Kurang Valid/layak digunakan & Revisi Sebagian \& Pengkajian Ulang Materi \\
$1,00<\bar{x} \leq 1,76$ & Tidak Valid/layak digunakan & Revisi Total \\
\hline
\end{tabular}

Sumber : Maskur, et. al. (2017)

Analisa data uji coba produk atau angket respon peserta didik memiliki 4 pilihan jawaban yang berbeda, ini bertujuan agar diketahui tingkat kemenarikan produk Teknik analisis data kemenarikan menggunakan skor rata-rata akhir penilaian angket respon peserta didik yang diperoleh dari Skala Likert. Tabel 2. berikut berisikan 4 acuan kriteria, guna mengetahui tingkat kemenarikan pada angket terhadap bahan ajar yang dikembangkan.

Tabel 2. Kriteria Uji Kemenarikan (Dimodifikasi)

\begin{tabular}{cc}
\hline Kriteria Kualitas Aspek Kemenarikan & Skor Kualitas \\
\hline Sangat Menarik & $3,26<\bar{x} \leq 4,00$ \\
Menarik & $2,51<\bar{x} \leq 3,26$ \\
Kurang Menarik & $1,76<\bar{x} \leq 2,51$ \\
Sangat Kurang Menarik & $1,00<\bar{x} \leq 1,76$ \\
\hline
\end{tabular}

Sumber: Putra, et. al. (2017)

Analisis efektifitas dilakukan dengan memberikan pretest dan postest kepada peserta didik. Hasil pretest dan postest ini dihitung menggunakan rumus uji Effect Size. Sementara itu kategori dari nilai uji Effect Size dapat dilihat dalam Tabel 3..

Tabel 3. Kategori Effect Size

\begin{tabular}{lc}
\hline \multicolumn{1}{c}{ Kategori } & Effect Size \\
\hline Rendah & $d \leq 0,2$ \\
Sedang & $0,2<d \leq 0,8$ \\
Tinggi & $d>0,8$ \\
\hline \multicolumn{2}{l}{ Sumber: Erpina, et. al. $(2014)$}
\end{tabular}

HASIL

Pada bagian hasil penelitian ini, diuraikan beradasarkan dari langkah penelitian dengan mengacu pada tahapan dalam pengembangan ADDIE.

1. Analysis (analisis)

Mula-mula tahapan yang dilakukan adalah analisis, yang mencakup a) guna menemukan kesulitan peserta didik kelas VII salah satu MTs Swasta di Sukarame, Bandar Lampung dalam proses pembelajaran dilakukan analisis kebutuhan. b) Peneliti menganalisis kurikulum yang digunakan pada pembelajaran di MTs Muhammadiyah Sukarame Bandar Lampung dan kesesuaian dengan bahan ajar yang dikembangkan yaitu kurikulum K-13 edisi revisi 2020. c) 
Menelaah ciri khas peserta didik yang berkenaan dengan pengetahuan, sikap, serta keterampilan yang telah dimiliki peserta didik.

2. Design (desain/perencanaan)

Tahap perencanaan merupakan tahap untuk menerapkan instruksi pada tahap analisis. Dapat diartikan juga tahap untuk membuat strategi yang dapat dilakukan guna mencapai tujuan pembelajaran. Guna melakukan pengembangan modul bernuansa Islam dilengkapi rumus cepat peneliti menyusun suatu strategi pengembangan produk. Agar mencapai tujuan yang sudah ditargetkan peneliti dengan lebih cepat dan mudah desain modul perlu dilengkapi komponenkomponen yang mendukung. Modul memuat komponen pendukung yang terdiri dari adanya renungan, desain tambilan dan motivasi guna tercapainya tujuan dari pembelajaran.

3. Development (pengembangan)

Selanjutnya adalah pengembangan bahan ajar, setelah melakukan tahapan analisis serta membuat desain atau blueprint. Sesuai dengan desain yang sudah dibuat draf bisa dikembangkan. Dalam penelitian ini peneliti membuat draf modul bernuansa Islam dilengkapi rumus cepat, validasi produk akan dilakukan setelah draf modul selesai dikembangkan. Pada tahap pengembangan dilakukan beberapa evaluasi guna menghasilkan produk yang yang layak, menarik, serta efektif.

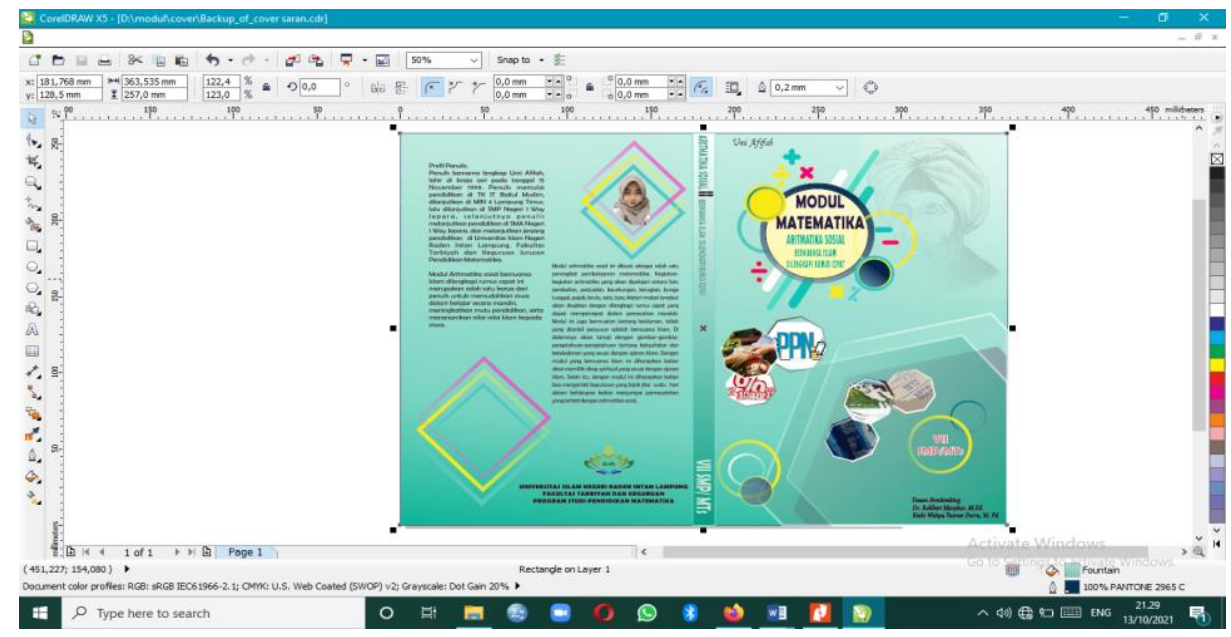

Gambar 1. Pembuatan Cover Modul

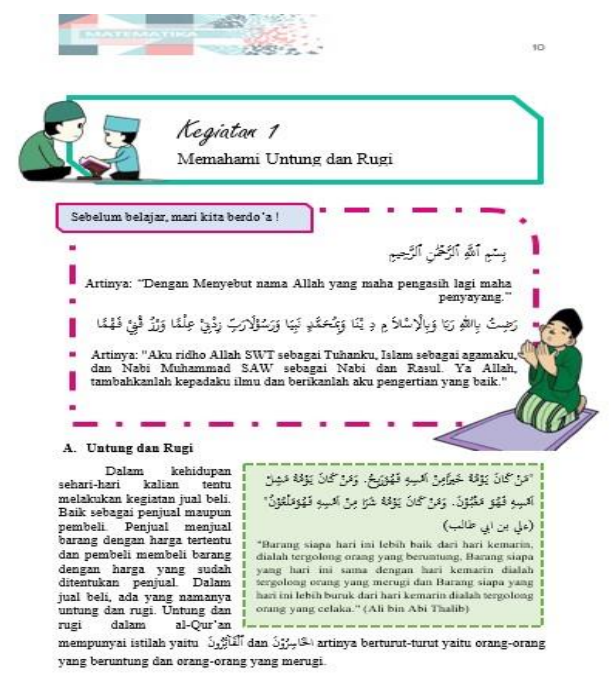

Gambar 2. Materi pada Modul 
Pada tahap pengembangan $d r a f t$ bahan ajar yang dihasilkan selanjutnya akan divalidasi oleh ahli materi dan media, serta pendidik mata pelajaran matematika. Sekilas gambaran terkait cover dan materi hasil pengembangan draft disajikan dalam Gambar 1. dan Gambar 2.. Bahan ajar berupa modul divalidasi oleh dua ahli materi dan media dari dosen pendidikan matematika UIN Raden Intan Lampung dan satu pendidik mata pelajaran matematika MTs Swasta di Sukarame, Bandar Lampung, serta dua ahli agama dari dosen pendidikan agama Islam UIN Raden Intan Lampung dan satu pendidik mata pelajaran agama MTs Swasta di Sukarame, Bandar Lampung. Penilaian bahan ajar yang divalidasi oleh validator (orang yang mahir dalam materi dan media, agama, dan pendidik matematika) pertanyaan yang ada pada lembar peniliaian dilihat pada beberapa aspek. Aspek-aspek yang terdapat dalam lembar validasi ahli materi dan media mencakup identitas cover, ukuran modul, desain sampul modul (cover), standar isi, petunjuk kegiatan, petunjuk dan arahan, kegiatan pembelajaran, desain isi modul, tata bahasa dan ejaan, prinsip ilmiah, penyajian informasi, penyajian kegiatan isi pembelajaran materi, kualitas isi, ketepatan cakupan, prinsip relevan, ranah kompetensi, dan prinsip sistematis. Aspek-aspek yang terdapat dalam lembar validasi ahli agama mencakup aspek penyajian informasi, prinsip sistematis, prinsip ilmiah, ketepatan isi dengan nilai-nilai agama Islam, struktur bahasa dan kalimat.

Hasil dari validasi dengan penilaian yang dilakukan oleh 3 validator. Aspek-aspek yang terdapat dalam lembar validasi mencakup identitas cover, ukuran modul, desain sampul modul (cover), standar isi, petunjuk kegiatan, petunjuk dan arahan, kegiatan pembelajaran, desain isi modul, tata bahasa dan ejaan, prinsip ilmiah, penyajian informasi, penyajian kegiatan isi pembelajaran materi, prinsip relevan, ranah kompetensi, kualitas isi, ketepatan cakupan, dan prinsip sistematis.

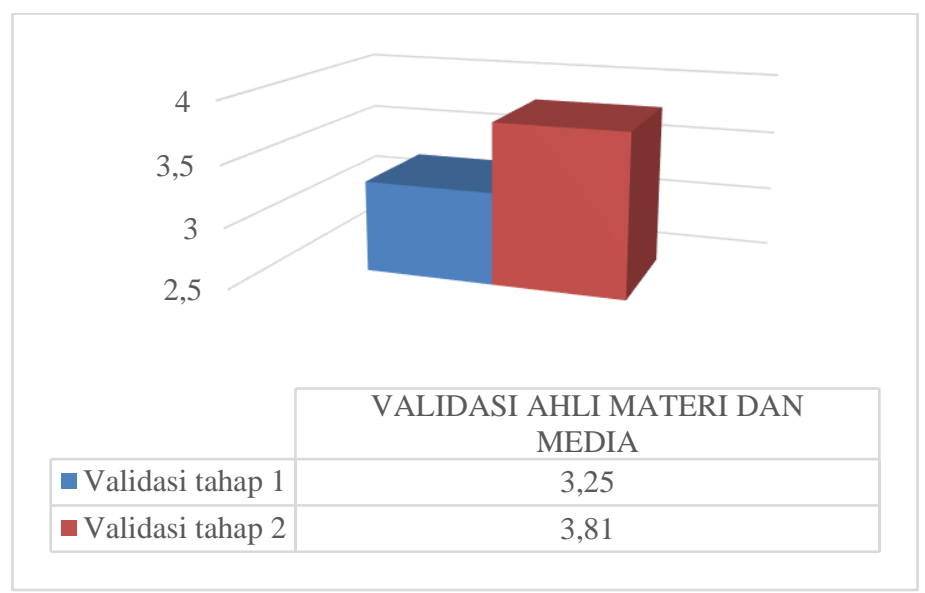

Gambar 3. Hasil Validasi Ahli Materi dan Media

Berdasarkan Gambar 3. hasil validasi dari ahli materi dan media pada produk awal, diperoleh nilai rata-rata akhir 3,25 yang dinyatakan bahan ajar matematika kelas VII SMP/MTs pada materi aritmatika sosial bernuansa Islam dilengkapi rumus cepat memiliki kriteria cukup layak digunakan. Hasil dari validasi pada tahap dua dipaparkan nilai rata-rata semua aspek yaitu 3,81 maka bahan ajar memiliki kriteria layak untuk digunakan. 


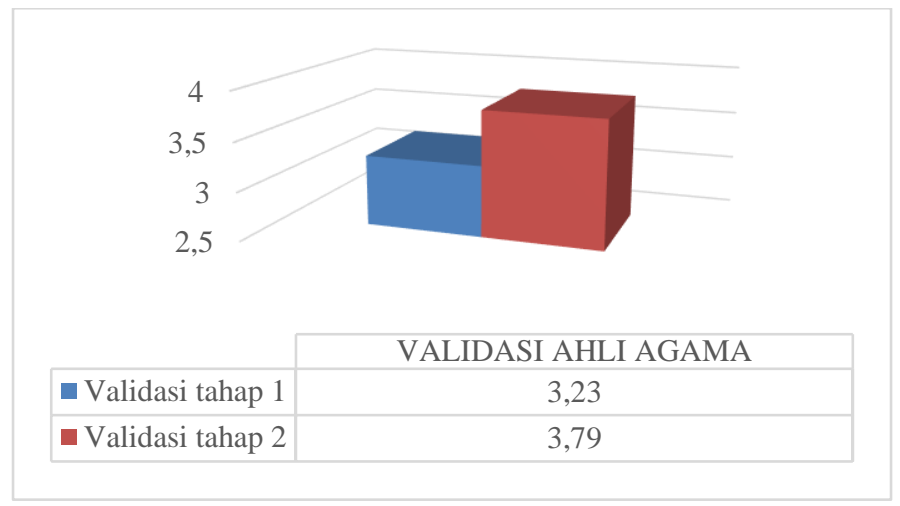

Gambar 4. Hasil Validasi Ahli Agama

Gambar 4. memaparkan hasil dari validasi oleh validator ahli agama. Penilaian di atas berdasarkan aspek penyajian informasi, prinsip sistematis, prinsip ilmiah, ketepatan isi dengan nilai-nilai agama islam, struktur bahasa dan kalimat. Skor rata-rata dari validasi tahap awal yang memuat lima aspek adalah sebesar 3,23 dengan kategori cukup layak digunakan. Hasil dari validasi tahap dua dengan skor rata-rata seluruh aspek yaitu 3,79 dengan kriteria layak digunakan.

4. Implementation (implementasi)

Tahapan yang berikutnya adalah tahap implementasi yang dilakukan setelah produk selesai divalidasi oleh para ahli. Tahap implementasi yaitu tahap pengujian lapangan dalam model pengembangan ADDIE. Pada proses ini peneliti mengubah suatu rencana menjadi suatu tindakan, untuk menunjang pembelajaran dilakukan penerapan modul yang sudah valid. Modul yang valid diimplementasikan kepada kelas eksperimen berperan menjadi sampelnya. Rata-rata nilai validasi yang didapatkan dari para ahli dinyatakan bahwa produk "layak digunakan", maka produk dapat digunakan dalam proses uji coba produk. Dua tahapan yaitu uji coba kelompok kecil dan uji coba kelompok besar dilakukan pada tahap uji coba produk. Perbandingan hasil dari uji coba produk dalam skala kecil dan skala besar disajikan dalam diagram pada Gambar $5 .$.

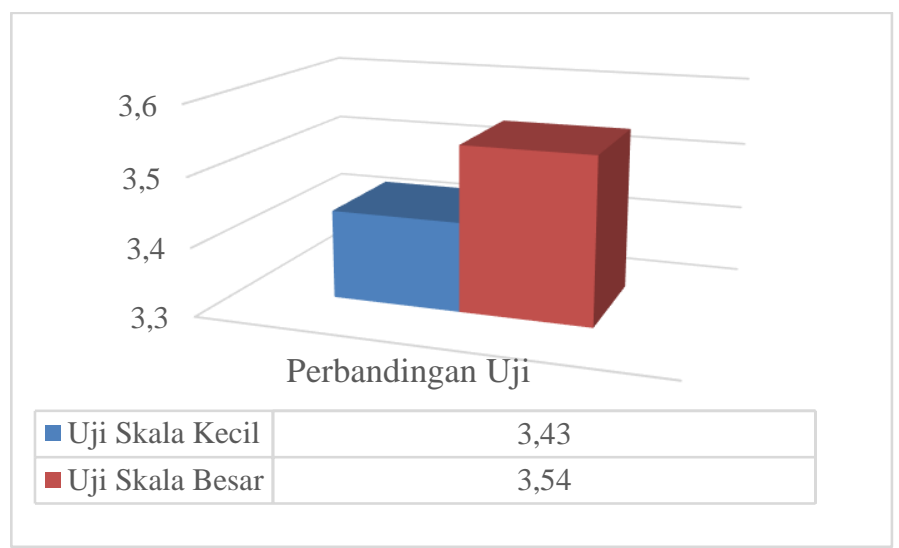

\section{Gambar 5. Perbandingan Hasil Uji Skala Kecil dengan Hasil Uji Skala Besar}

Gambar 5. memaparkan grafik yang membandingkan antara uji skala kecil dan uji skala besar, uji skala kecil melibatkan 10 peserta didik dengan skor rata-rata 3,43 dengan kriteria "sangat menarik" dan uji skala besar melibatkan 30 peserta didik dengan memperoleh skor rata-rata sebesar 3,54 dengan kriteria "sangat menarik". Peningkatan jumlah peserta didik dalam uji skala besar mempengaruhi peningkatan skor kemenarikan bahan ajar.

Pelaksanaan uji efektivitas terhadap peserta didik dilakukan dengan cara memberikan pretest dan postest. Kelas eksperimen dipilih dengan teknik cluster random sampling yaitu teknik yang dipakai untuk mengambil sampel dengan cara melakukan pengelompokan kelas lalu dipilih secara acak. Berikut adalah perhitungan effect size yang dipaparkan pada Tabel 4 .. 
Tabel 4. Perhitungan Effect Size

\begin{tabular}{ccccc}
\hline Kategori & N & Rata-rata & Standar Deviasi & Effect Size \\
\hline Pretest & 30 & 46,43 & 46,72 & 0,43 \\
postest & 30 & 72,33333 & 71,92 & \\
\hline
\end{tabular}

Sumber: Diolah dari data penelitian, 2021

Pada Tabel 4. dipaparkan perhitungan data dengan perhitungan effect size. Diketahui nilai rata-rata pretest dan postest, standar deviasi pretest dan postest, dan effect size dari Tabel 4. Nilai rata-rata pretest adalah 46,43 dan rata-rata nilai postest adalah 72,33 . Standar deviasi pada pretest adalah sebesar 46,72 sedangkan standar deviasi pada postest ialah 71,92. Effect size yang diperoleh adalah sebesar 0,43 dan dapat disimpulkan bahwa bahan ajar yang dihasilkan cukup efektif digunakan dalam pembelajaran dan dapat diimplementasikan dalam proses pembelajaran materi aritmatika sosial.

5. Evaluation (evaluasi)

Evaluasi dapat dilaksanakan di semua tahapan dalam pengembangan ADDIE. Tahapan design, dosen pembimbing yang melakukan evaluasi. lalu saat tahapan pengembangan, tim validator beserta dosen pembimbing yang melakukan evaluasi. Serta untuk tahapan implementasi, peserta didik sebagai subjek penelitian diminta melakukan evaluasi bahan ajar berupa modul pembelajaran matematika pada pokok materi aritmatika sosial bernuansa Islam dilengkapi rumus cepat. Peneliti mengevaluasi modul pembelajaran yang telah diimplementasikan. Tahap ini dilakukan untuk perbaikan terhadap modul yang telah dikembangkan.

\section{PEMBAHASAN}

Peneliti melakukan tahap awal adalah tahapan analisis, pada tahapan ini diketahui masalah yang terdapat di MTs Swasta di Sukarame, Bandar Lampung peneliti menganalisis kebutuhan peserta didik. Berdasarkan wawancara yang dilakukan dengan pendidik peneliti mendapatkan hasil analisis kebutuhan adalah dalam proses pembelajaran bahan ajar yang digunakan kurang menarik minat peserta didik dalam belajar serta sulit dipahami oleh peserta didik, menurut pendidik perlu adanya pengembangan bahan ajar dengan nuansa Islam guna meningkatkan sikap spiritual dalam kehidupan sehari-hari peserta didik. Banyaknya rumus dalam materi aritmatika sosial membuat peserta didik kesulitan dalam mengingat rumus serta kepercayaan diri peserta didik yang kurang dalam memecahkan soal cerita, serta diperlukannya pembelajaran dengan bahan ajar bernuansa Islam dengan tujuan meningkatkan sikap spiritual peserta didik.

Tahap perancangan (design) adalah tahap selanjutnya. Tahapan ini adalah tahap menyusun rancangan bahan ajar matematika kelas VII SMP/MTs pada materi aritmatika sosial bernuansa Islam dilengkapi rumus cepat. Kompetensi dasar harus disesuaikan dengan isi materi dalam susunan desain penyajian. Peneliti melakukan perancangan instrumen angket validasi serta angket respon peserta didik guna mengevaluasi bahan ajar matematika kelas VII SMP/MTs pada materi aritmatika sosial bernuansa Islam dilengkapi rumus cepat, serta dilanjutkan dengan tahap pengembangan. Tahapan pengembangan adalah tahapan dimana peneliti membuat bahan ajar matematika kelas VII SMP/MTs pada materi aritmatika sosial bernuansa Islam dilengkapi rumus cepat. Konsultasi kepada dosen pembimbing dilakukan setelah bahan ajar selesai dibuat guna memperoleh kritik serta saran perbaikan bahan ajar sebelum melakukan tahapan validasi. Tahapan validasi dilakukan untuk mengukur dan menemukan kekurangan dalam bahan ajar yang dikembangkan melalui masukan dan saran yang diberikan oleh validator supaya peneliti dapat memperbaiki bahan ajar dan bahan ajar dapat dikatakan layak atau valid.

Validasi bahan ajar dilakukan oleh para ahli, terdapat 3 ahli materi dan media serta 3 ahli agama. Penilaian validator ahli materi dan media yang dihasilkan meliputi 17 aspek di mana rata-rata akhir dari validasi tahap awal dengan kriteria cukup layak digunakan memiliki nilai rata-rata sebesar 3,25 dan rata-rata akhir validasi setelah revisi adalah sebesar 3,81 dengan kriteria layak digunakan. 
Adapun aspek kesesuaian materi dengan nuansa Islam yang dimuat dalam bahan ajar merupakan hasil penilaian validator ahli agama didapat nilai rata-rata validasi tahap awal sebesar 3,23 dengen kriteria cukup layak digunakan dan validasi setelah revisi adalah sebesar 3,79 dengan kriteria layak digunakan. Selain disajikan ke dalam bentuk tabel, hasil validasi yang diberikan oleh ahli materi dan media serta ahli agama juga ditampilkan dengan bentuk grafik.

Tahapan berikutnya ialah tahapan implementasi (implementation) yang merupakan tahapan dimana peneliti melaksanakan uji coba skala kecil, uji coba skala besar, dan uji efektivitas. Cara mengukur dan mengetahui kemenarikan bahan ajar matematika kelas VII SMP/MTs pada materi aritmatika sosial bernuansa Islam dilengkapi rumus cepat yang dikembangkan peneliti melakukan uji skala kecil dan uji skala besar, dengan memberikan angket respon peserta didik. Uji coba skala kecil melibatkan 10 peserta didik yang dipilih dengan acak dan mendapatkan rata-rata dari hasil olah data angket respon peserta didik sebesar 3,43 yang artinya memiliki kriteria sangat menarik. Sedangkan hasil olah data dari angket respon peserta didik pada uji coba skala besar yang melibatkan 30 peserta didik dengan kriteria sangat menarik mendapatkan nilai rata-rata sebesar 3,54. Maka, bahan ajar layak untuk diimplementasikan pada proses pembelajaran aritmatika sosial ditinjau dari nilai rata-rata uji skala kecil dan uji skala besar yang sudah memenuhi aspek kemenarikan. Hambatan pada tahap implementasi ditemui kesulitan dalam penyampaian materi disaat signal tidak mendukung untuk pembelajaran melalui zoom meeting. Pada tahapan implementasi peneliti melakukan 3 uji diantaranya yaitu uji skala kecil, uji skala besar, dan uji efektifitas. Kegiatan pembelajaran dilakukan peneliti menggunakan zoom meeting dengan materi yang diajarkan adalah materi aritmatika sosial sesuai materi yang dikembangkan dalam bahan ajar. Kemudian dilakukan uji skala kecil dengan melibatkan 10 orang yang peserta didik dan uji skala besar dilakukan dengan melibatkan 30 orang peserta didik kelas VIII MTs Sukarame Bandar Lampung dengan menyebar angket respon peserta didik guna mengetahui dan mengukur kemenarikan bahan ajar yang dikembangkan. Sampel diambil dengan teknik cluster random sampling. Uji efektivitas adalah uji terakhir, dimana kelas eksperimen diberikan pretest pada awal pembelajaran dan postest pada akhir pembelajaran kepada 30 peserta didik. Peneliti melakukan uji efektivitas guna mengetahui keefektifan bahan ajar yang dikembangkan pada akhir kegiatan pembelajaran diberikan postest guna mengukur efektivitas bahan ajar diberikan durasi 20 menit.

Keefektifitasan bahan ajar dalam pembelajaran dapat diukur dengan uji efektivitas. Pretest dan postest peserta didik kelas eksperimen menghasilkan nilai guna Uji efektivitas. Uji effect size dilakukan untuk menganalisis hasil nilai pretest dan postest peserta didik kelas eksperimen. Hasil yang didapatkan dari perhitungan nilai rata-rata pretest adalah sebesar 46,43 dan hasil yang didapatkan dari perhitungan nilai rata-rata postest adalah sebesar 72,33. Besar standar deviasi pretest adalah 46,72 dan besar standar deviasi postest ialah 1,92. Sedangkan nilai effect size yang didapat adalah sebesar 0,43, ini menunjukkan bahwa bahan ajar cukup efektif digunakan dalam proses pembelajaran. Tahapan yang terakhir pada model ADDIE adalah tahapan evaluasi (evaluation), tahap evaluasi dilakukan pada semua tahap untuk menemukan kekurangan serta mengoreksi setiap tahapan yang telah dilakukan.

Penelitian pengembangan model ADDIE dilakukan dengan lima tahapan dan menghasilkan produk akhir yaitu bahan ajar matematika kelas VII SMP/MTs pada materi aritmatika sosial bernuansa Islam dilengkapi rumus cepat yang sudah berkualifikasi layak, menarik, dan efektif digunakan dalam proses pembelajaran. Diharapkan bahan ajar ini mampu membantu peserta didik juga pendidik dalam pelaksanaan proses pembelajaran. Hambatan yang yang didapati oleh peneliti yaitu pada tahap analisis adalah perlunya menganalisis data hasil ujian harian peserta didik yang telah diberikan oleh pendidik dan menentukan kebutuhan peserta didik. Hambatan pada tahapan desain adalah penggunaan aplikasi CorelDraw untuk membuat cover bagian depan dan belakang. Selanjutnya pada tahap development peneliti mendapatkan hambatan di mana pengembangan harus menyesuaikan materi dengan nuansa Islam yang dapat dituangkan dalam bahan ajar. Revisi produk 
dilakukan oleh peneliti sesuai dengan masukan validator sampai produk dinyatakan layak digunakan dalam proses pembelajaran.

Penelitian yang telah dilakukan sebelumnya memiliki kemiripan dengan penelitian yang dilakukan oleh peneliti, di mana sama-sama melakukan penelitian dan pengembangan bahan ajar dengan dilengkapi rumus cepat, adanya keterbaruan dalam penelitian yang dilakukan peneliti yaitu muatan nuansa Islam yang dikembangkan oleh peneliti dalam mengembangkan bahan ajar matematika kelas VII SMP/MTs pada materi aritmatika sosial bernuansa Islam dilengkapi rumus cepat. Keungulan bahan ajar yang dikembangkan oleh peneliti adalah bahan ajar memuat nuansa Islam yang bertujuan mengembangkan sikap spiritual peserta didik. Bahan ajar juga dilengkapi dengan rumus cepat guna memudahkan peserta didik dalam menyelesaikan soal. Pengembangan bahan ajar ini menggunakan aplikasi Microsoft word yang sangat mudah digunakan serta menggunakan CorelDraw untuk membuat cover bagian depan dan belakang. Bahan ajar matematika kelas VII SMP/MTs pada materi aritmatika sosial bernuansa Islam dilengkapi rumus cepat dikembangkan guna membantu proses pembelajaran matematika dan meningkatkan kepercayaan diri peserta didik dalam memecahkan soal.

\section{SIMPULAN}

Kesimpulan dari penelitian adalah bahan ajar dikembangkan oleh peneliti menggunakan jenis penelitian R\&D (research and development), model yang digunakan adalah model ADDIE (analysis, design, development, implementation, and evaluation). Kelayakan bahan ajar didapatkan dari uji kelayakan saat validasi oleh ahli materi dan media yaitu dengan nilai 3,81 dengan kriteria valid dan rata-rata nilai kelayakan ahli agama yaitu 3,79 dengan kriteria valid. Uji kemenarikan ditinjau dari hasil penilaian respon peserta didik terhadap bahan ajar mendapat nilai 3,43 untuk uji skala kecil dengan kriteria sangat menarik dan dan 3,54 untuk uji skala besar dengan kriteria sangat menarik. Penilaian uji efektivitas bahan ajar mendapatkan skor effect size sebesar 0,43 dengan kategori sedang dan efektif untuk digunakan saat pembelajaran. Saran penulis untuk penelitian selanjutnya adalah mengujicobakan kegiatan pembelajaran menggunakan bahan ajar matematika kelas VII SMP/MTs pada materi aritmatika sosial bernuansa Islam dilengkapi rumus cepat pada subjek penelitian yang berbeda.

\section{DAFTAR RUJUKAN}

Aldoobie, N. (2015). ADDIE Model. American International Journal of Contemporary Research, $5(6), 68-72$.

Arifah, U., \& Saefudin, A. A. (2017). Menumbuhkembangkan kemampuan pemahaman konsep matematika dengan menggunakan model pembelajaran guided discovery. UNION: Jurnal Pendidikan Matematika, 5(3), 263-272. https://doi.org/https://doi.org/10.30738/.v5i3.1251

Erpina, Hasjmy, M. A., \& Salimi, A. (2014). Pengaruh Kooperatif Teknik Talking Stick terhadap Hasil Pembelajaran Pendidikan Kewarganegaraan di SD. Jurnal Pendidikan Dan Pembelajaran Untan, 3(9). https://www.neliti.com/publications/215454/pengaruh-kooperatif-teknik-talkingstick-terhadap-hasil-pembelajaran-pendidikan\#cite

Fitriyana, Z. N., Mailizar, M., \& Seruni, S. (2021). Pengembangan Modul Pembelajaran Matematika dengan Pendekatan Matematika Realistik. JKPM (Jurnal Kajian Pendidikan Matematika), 6(2), 279-292. https://doi.org/http://dx.doi.org/10.30998/jkpm.v6i2.10014

Hamdani. (2011). Strategi Belajar Mengajar. Bandung: Pustaka Setia.

Herdianto, H., Putra, R. W. Y., \& Anggoro, B. S. (2018). Pengembangan Modul Berbantuan Rumus Cepat Arimetika Sosial Dan Perbandingan. Nabla Dewantara: Jurnal Pendidikan Matematika, 3(2), 17-30. http://ejournal.unitaspalembang.ac.id/index.php/nabla/article/view/88

Mardati, A. (2017). Pengembangan Modul Matematika Dengan Pendekatan Kontekstual Pada Materi 
Bangun Datar Untuk Mahasiswa PGSD UAD. JPSD Journal (Jurnal Pendidikan Sekolah Dasar), 4(1), 1-7. http://journal.uad.ac.id/index.php/JPSD/article/view/7246

Maskur, R., Nofrizal, N., \& Syazali, M. (2017). Pengembangan Media Pembelajaran Matematika dengan Macromedia Flash. Al-Jabar: Jurnal Pendidikan Matematika, 8(2), 177-186.

Mulyatna, F., Imswatama, A., \& Rahmawati, N. D. (2021). Design Ethnic-Math HOTS: Mathematics Higher Order Thinking Skill Questions Based On Culture and Local Wisdom. Malikussaleh Journal of Mathematics Learning (MJML), 4(1), 48. https://doi.org/10.29103/mjml.v4i1.3059

Putra, R. W. Y., \& Anggraini, R. (2016). Pengembangan Bahan Ajar Materi Trigonometri Berbantuan Software iMindMap pada Siswa SMA. Al-Jabar: Jurnal Pendidikan Matematika, 7(1), 39-47. https://doi.org/https://doi.org/10.24042/ajpm.v7i1.9696

Putra, R. W. Y., Nurwani, Putra, F. G., \& Putra, N. W. (2017). Pengembangan Desain Didaktis Bahan Ajar Materi Pemfaktoran Bentuk Aljabar pada Pembelajaran Matematika. Numerical: Jurnal Matematika Dan Pendidikan, 1(2), 97-102. https://doi.org/https://doi.org/10.25217/numerical.v1i2.133

Rachmawaty, L. (2020). Peningkatan Hasil Belajar Peserta Didik pada Mata Pelajaran Matematika Tentang Faktor dan Kelipatan Bilangan Melalui Penerapan Model Pembelajaran Kooperatif Tipe Make A Match di Kelas IV SDN Polisi 5 Kota Bogor. Jurnal Edukha, 1(1), 13-26. https://doi.org/http://dx.doi.org/10.32832/edukha.v1i1.3203

Siagian, M. D. (2016). Kemampuan koneksi matematik dalam pembelajaran matematika. MES: Journal of Mathematics Education and Science, 2(1), 58-67. https://doi.org/https://doi.org/10.30743/mes.v2i1.117

Sina, I. (2011). Implementasi Model Pembelajaran Role Playing Didasari Analisis Swot Pada Materi Peluang: Penelitian Tindakan Kelas Pada Kelas XI SMA N 1 Wanasari. Cakrawala: Jurnal Pendidikan, 6(1), 1. http://e-journal.upstegal.ac.id/index.php/Cakrawala/article/view/69

Situorang, E. (2017). Meningkatkan Hasil Belajar Matematika dengan Metode Group Investigation Berbasis Kontekstual Materi Statistika Kelas XI SMA Negeri 1 Parbuluan. Keguruan, 5(2), 8 15. https://jurnal.uisu.ac.id/index.php/Keguruan/article/view/824

Sugiyono. (2017). Metode Penelitian Pendidikan (Pendekatan Kuantitatif, Kualitatif, Dan R\&D). Bandung: Alfabeta. 
70 Afifah, dkk 